\title{
A Study on aerobic Bacteriological profile and Drug sensitivity pattern of Pus samples in a tertiary care hospital
}

\author{
Pushpalatha Hanumanthappa*, B. Vishalakshi and S. Krishna \\ Department of Microbiology, Vijayanagar Institute of Medical Sciences, Ballari, India \\ *Corresponding author
}

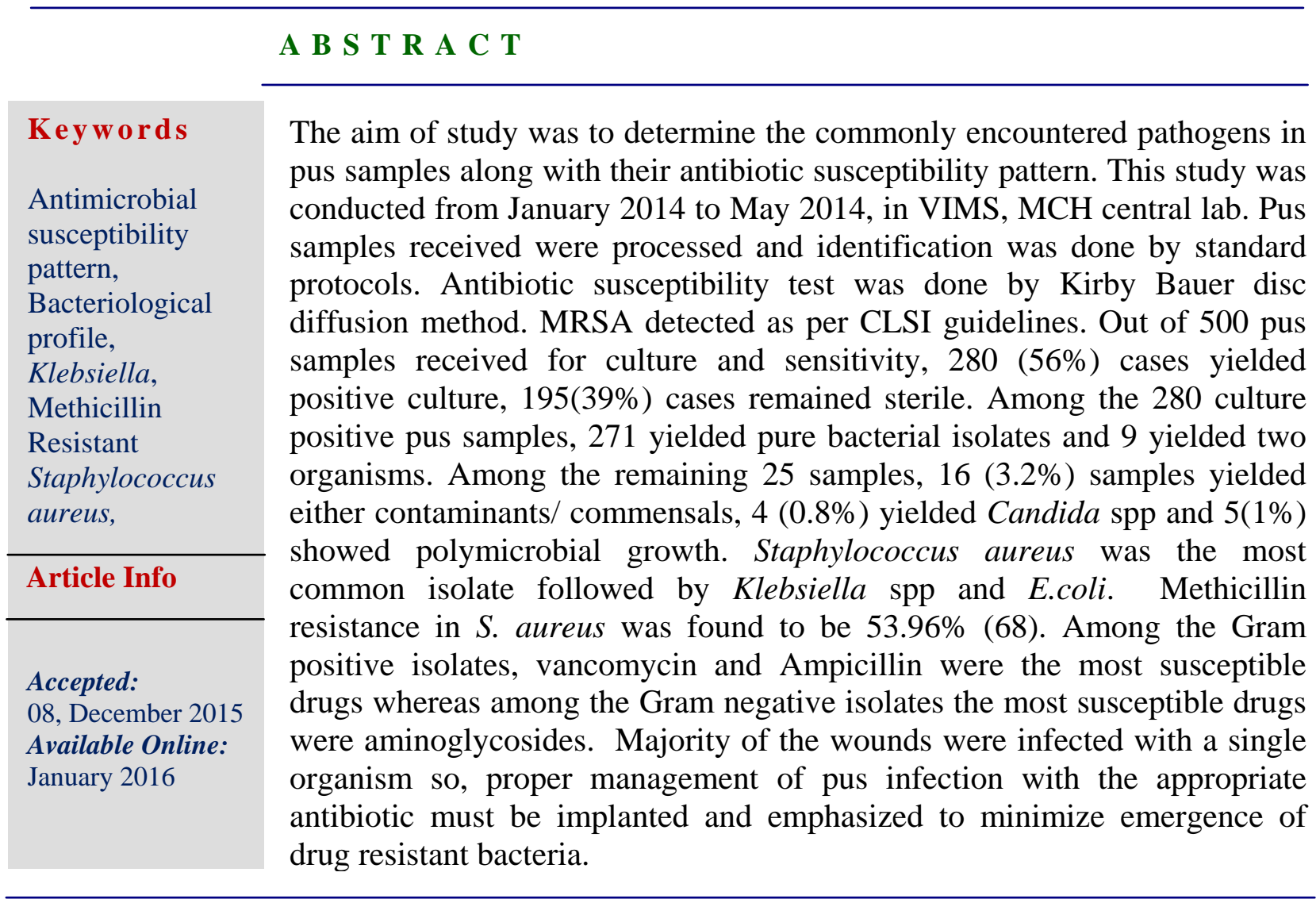

\section{Introduction}

Pyogenic infection is one of the major complications of surgery and trauma. The factors which contribute to pyogenic infections include preexisting illness, length of operation, wound class and wound contamination (Ramesh Rao et al., 2013).
These infections may be endogenous or exogenous (Koneman et al., 2005) or it may be polymicrobial or monomicrobial in nature (Jeffery stone et al, 1997).

The pathogens isolated from infections 
differ depending on the underlying problem, location and type of surgical procedure. (Ramesh Rao et al., 2013). Most common organisms encountered are Staphylococcus aureus, Klebsiella spp., Escherichia coli, Pseudomonas spp., Proteus spp., Enterococci spp (Krige J.E.J., and Beckingham J.I, 2001) Enterobacter, Proteus spp, Candida and Acinetobacter spp (Tayfour MA et al., 2005).

For prevention \& cure of pyogenic infections, antibiotics play a key role. To select an appropriate antibiotic needs knowledge of the potential microbial pathogen, its pathophysiological role in the infectious process and an understanding of the pharmacology and pharmacokinetics of the intended antibiotics. (Kelwin W.S,1999)

There is a need of regular analysis of the profile and antibiogram of organisms isolated and the results need to be communicated to clinician. So, the present study was undertaken to evaluate aerobic bacteriological profile along with their susceptibility to antimicrobial agents.

\section{Materials and Methods}

\section{Study Setting}

The study population was of patients irrespective of age and sex either admitted to different wards in hospital or visiting the out-patient department.

\section{Study Period}

Record based observational study was conducted at VIMS, MCH Ballari over a five months period from January 2014 to may 2014.

\section{Exclusion Criteria}

Diphtheroids, environmental bacillus species and $>=3$ agents (contaminants) in the samples.

A total number of 500 pus samples received for aerobic culture and sensitivity from different wards \& OPDs in Microbiology Central laboratory of VIMS MCH Hospital, Ballari during a period from January to May 2014 were included in the study. Informed consent was taken from the patient and ethical clearance was obtained from the institute.

Taking aseptic precautions, lesions were cleaned with sterile normal saline. With proper care, avoiding contamination by the normal flora of skin or mucus surface, the pus was aspirated or exudate collected. The specimens were transported in sterile, leakproof containers to the lab immediately or if there was a delay, stored at $4^{0} \mathrm{C}$; those with refrigeration of more than 24 hours were not processed.

The pus samples were subjected for gram stain to look for pus cells and organisms. Specimens were inoculated on blood agar and MacConkey agar plates and incubated overnight at $37^{\circ} \mathrm{C}$. Pathogens were identified by conventional biochemical methods according to standard microbiological techniques (Collec JG et al., 1996).

The antimicrobial susceptibility testing was done by Kirby Bauer's Disk Diffusion method and interpreted as per Clinical Laboratory Standard Institution (CLSI) guidelines (CLSI, 2012).

Standard antibiotics like, ampicillin (10 $\mathrm{mcg}$ ), vancomycin (30 mcg), ceftriaxone (30 $\mathrm{mcg}$ ), cefotaxime (30 mcg), ceftazidime (30 $\mathrm{mcg}$ ), ciprofloxacin (5mcg), co-trimoxazole $(1.25 / 23.75 \mathrm{mcg})$, gentamycin $(10 \mathrm{mcg})$, amikacin $(30 \mathrm{mcg})$, clindamycin $(2 \mathrm{mcg})$ and erythromycin $(15 \mathrm{mcg})$, Cefoxitin (30 mcg) 
were tested (Himedia, Mumbai, India) (Betty A. Forbes et al., 2007)

\section{Detection of Methicillin Resistance}

The methicillin resistance in Staphylococcus spp. was tested by cefoxitin disc $(30 \mu \mathrm{g})$ as documented in Clinical and Laboratory Standard Institute (CLSI 2012). ( Cefoxitin disc diffusion of $\leq 21 \mathrm{~mm}$ for $S$. aureus). The positive culture reports were analysed and percentages and proportions were calculated.

\section{Results and Discussion}

Out of 500 pus samples received for culture and sensitivity in the Microbiology central laboratory, $280(56 \%)$ cases yielded positive culture, $195(39 \%)$ cases remained sterile even after 48hrs incubation. Among the 280 culture positive pus samples, 271 yielded pure bacterial isolates and 9 yielded two organisms; so a total number of 289 organisms were isolated out of 500 pus samples. Among the remaining 25 samples, $16(3.2 \%)$ samples yielded either contaminants/ commensals, $4(0.8 \%)$ yielded Candida spp and 5(1\%) showed polymicrobial growth $(>=3$ organisms) as shown in table 1.

Table.1 Rank order of pus samples isolates

\begin{tabular}{|l|c|}
\hline \multicolumn{1}{|c|}{ Rank order } & $\begin{array}{c}\text { Number of } \\
\text { samples }\end{array}$ \\
\hline Total & 500 \\
\hline $\begin{array}{l}\text { Aerobic growth with } \\
\text { one organism }\end{array}$ & 271 \\
\hline $\begin{array}{l}\text { Aerobic growth with } \\
\text { two organism }\end{array}$ & 9 \\
\hline No growth & 195 \\
\hline $\begin{array}{l}\text { Commensals/ } \\
\text { contaminants }\end{array}$ & 16 \\
\hline Polymicrobial (>=3 org) & 5 \\
\hline Candida spp & 4 \\
\hline
\end{tabular}

Of the 289 isolates, there were 157 (54.32\%) gram negative bacilli and 132 (45.67\%) gram positive cocci. Most common organism isolated was Staphylococcus aureus $126(43.6 \%)$ followed by Klebsiella spp 50 (17.3\%). Other isolates included were, E.coli 41(14.18\%), Pseudomonas spp 34(11.76\%), Citrobacter spp 16 (5.54\%), Proteus spp. $10(3.46 \%)$ Enterococcus spp $6 \quad(2.07 \%)$, Enterobacter spp 3 (1.03\%),Burkholderia spp 1 (0.35\%), Acinetobacter1 (0.35\%), and other nonfermenting gram negative bacillil $(0.35 \%)$.As shown in flow chart 1 .

Flow chart 1: Flow chart showing 289 aerobic bacterial isolates of pus samples

Table 2 Antibiotic sensitivity pattern of gram positive cocci

Among the $S$. aureus, vancomycin, Ampicillin and gentamicin were the most susceptible drugs with $87.3 \%, 59.5 \%$ and $59.5 \%$ respectively. And $S$. aureus showed least sensitivity to Cefotaxime, Erythromycin, Co-trimoxazole with $54.7 \%$, $53.9 \%$ and $52.3 \%$ respectively.

Enterococcus spp most sensitive to ampicillin, ceftriaxone and erythromycin with $66.6 \%, 50 \%$ and $50 \%$ respectively and least sensitive to $3^{\text {rd }}$ generation cephalosporines like cefotaxime and ceftazidime with $83.3 \%$ and $83.3 \%$ respectively.

Gram negative isolates are most sensitive to aminoglycosides and Ceftazidime and least sensitive to Ciprofloxacin, and Cotrimoxazole. The observations of our study coincide with the various studies across the country. The predominance of monomicrobial infections observed in our study is substantiated by a study done by Basu $\mathrm{S}$ et al (Basu S et al., 2009). 
Table.2 Antibiotic Sensitivity Pattern of Gram Positive Cocci

\begin{tabular}{|l|c|c|c|c|}
\hline Antibiotics( $\mu \mathrm{g} / \mathrm{disc})$ & \multicolumn{2}{|c|}{ S. aureus (126) } & \multicolumn{2}{c|}{ Enterococcus spp (6) } \\
\hline & $\mathrm{S}(\%)$ & $\mathrm{R}(\%)$ & $\mathrm{S}(\%)$ & $\mathrm{R}(\%)$ \\
\hline Ampicillin $(30)$ & $75(59.5)$ & $51(40.4)$ & $4(66.6)$ & $2(33.3)$ \\
\hline Amikacin(30) & $96(76.1)$ & $30(23.8)$ & $2(33.3)$ & $4(66.6)$ \\
\hline $\begin{array}{l}\text { Co-trimoxazole } \\
(1.25 / 23.75)\end{array}$ & $60(47.6)$ & $66(52.3)$ & - & - \\
\hline Ciprofloxacin(5) & $70(55.5)$ & $56(44.4)$ & $2(33.3)$ & $4(66.6)$ \\
\hline Ceftriaxone (30) & $66(52.3)$ & $60(47.6)$ & $3(50)$ & $3(50)$ \\
\hline Cefotaxime(30) & $57(45.2)$ & $69(54.7)$ & $1(16.6)$ & $5(83.3)$ \\
\hline Ceftazidime(30) & $61(48.4)$ & $65(51.5)$ & $1(16.6)$ & $5(83.3)$ \\
\hline Cefoxitin (30 ) & $58(46.1)$ & $68(53.9)$ & - & - \\
\hline Clindamycin (2) & $72(57.1)$ & $54(42.8)$ & $3(50)$ & $3(50)$ \\
\hline Erythromycin $(15)$ & $58(46.1)$ & $68(53.9)$ & $3(50)$ & $3(50)$ \\
\hline Gentamycin (10) & $75(59.5)$ & $51(40.4)$ & - & - \\
\hline Vancomycin (30) & $110(87.3)$ & $16(12.6)$ & - & - \\
\hline
\end{tabular}

Flow chart.1 Flow Chart Showing 289 Aerobic Bacterial Isolates of Pus Samples

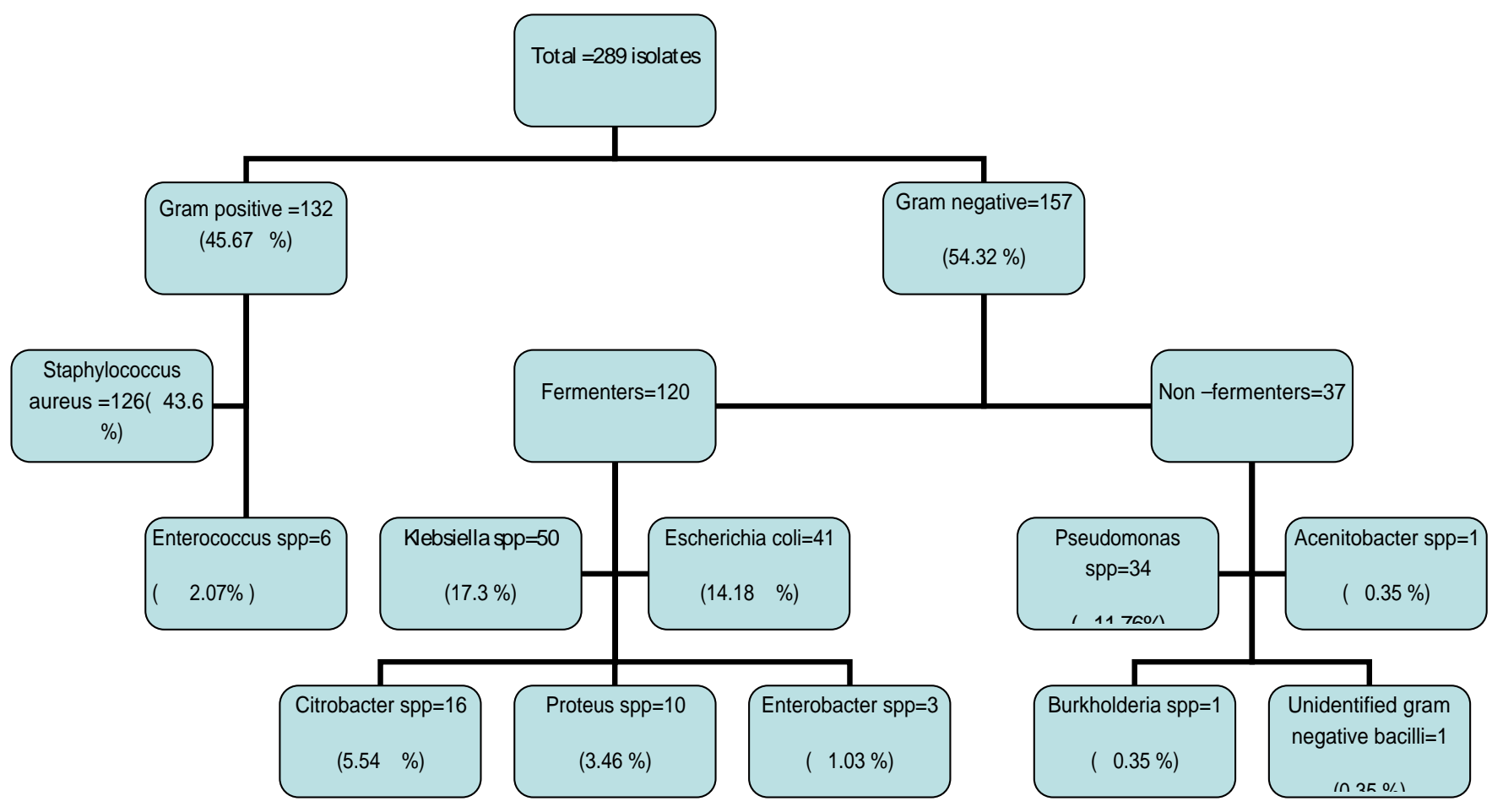


Table.3 Antibiotic Sensitivity Pattern of Gram Negative Bacilli

\begin{tabular}{|c|c|c|c|c|c|c|c|c|c|c|c|c|c|}
\hline \multirow[t]{2}{*}{$\begin{array}{l}\text { Sl. } \\
\text { No. }\end{array}$} & \multirow[t]{2}{*}{$\begin{array}{c}\text { Antibiotics } \\
(\mu \mathrm{g} / \text { disc })\end{array}$} & \multicolumn{2}{|c|}{ Klebsiella (50) } & \multicolumn{2}{|c|}{ E. coli $(41)$} & \multicolumn{2}{|c|}{$\begin{array}{c}\text { Citrobacter spp } \\
\text { (16) }\end{array}$} & \multicolumn{2}{|c|}{$\begin{array}{c}\text { Proteus spp } \\
\text { (10) }\end{array}$} & \multicolumn{2}{|c|}{ Enterobacter (3) } & \multicolumn{2}{|c|}{ Pseudomonas (34) } \\
\hline & & $\mathrm{S}(\%)$ & $\mathrm{R}(\%)$ & S (\%) & $\mathrm{R}(\%)$ & $\mathrm{S}(\%)$ & $\mathrm{R}(\%)$ & $\mathrm{S}(\%)$ & $\mathrm{R}(\%)$ & S (\%) & $\mathrm{R}(\%)$ & $\mathrm{S}(\%)$ & $\mathrm{R}(\%)$ \\
\hline 1. & $\begin{array}{l}\text { Ampicillin } \\
\text { (30) }\end{array}$ & $\begin{array}{c}20 \\
(40)\end{array}$ & $30(60)$ & $\begin{array}{c}15 \\
(36.5)\end{array}$ & $\begin{array}{c}26 \\
(63.5)\end{array}$ & $\begin{array}{c}9 \\
(56.2)\end{array}$ & $7(43.7)$ & $7(70)$ & $3(30)$ & $0(0)$ & $3(100)$ & - & - \\
\hline 2. & $\begin{array}{l}\text { Amikacin } \\
(30)\end{array}$ & $\begin{array}{c}37 \\
(74)\end{array}$ & $13(26)$ & $\begin{array}{c}25 \\
(60.9)\end{array}$ & $\begin{array}{c}16 \\
(39.1)\end{array}$ & $\begin{array}{c}9 \\
(56.2)\end{array}$ & $7(43.7)$ & $7(70)$ & $3(30)$ & $\begin{array}{c}2 \\
(66.66)\end{array}$ & $1(33.33)$ & $\begin{array}{c}19 \\
(55.9)\end{array}$ & $\begin{array}{c}15 \\
(44.11)\end{array}$ \\
\hline 3. & $\begin{array}{l}\text { Co- } \\
\text { trimoxazole } \\
(1.25 / 23.75) \\
\end{array}$ & - & - & $\begin{array}{c}11 \\
(26.8)\end{array}$ & $\begin{array}{c}30 \\
(73.1)\end{array}$ & - & - & - & - & $3(100)$ & $0(0)$ & - & - \\
\hline 4. & $\begin{array}{l}\text { Ciprofloxacin } \\
\text { (5) }\end{array}$ & $\begin{array}{c}19 \\
(38)\end{array}$ & $31(62)$ & $\begin{array}{c}18 \\
(43.9)\end{array}$ & $\begin{array}{c}23 \\
(56.1)\end{array}$ & $\begin{array}{c}6 \\
(37.5)\end{array}$ & $\begin{array}{c}10 \\
(62.5)\end{array}$ & $4(40)$ & $6(60)$ & $0(0)$ & $3(100)$ & $\begin{array}{c}14 \\
(41.17)\end{array}$ & $20(58.8)$ \\
\hline 5. & $\begin{array}{l}\text { Ceftriaxone } \\
(30)\end{array}$ & $\begin{array}{c}24 \\
(48)\end{array}$ & $26(52)$ & $\begin{array}{c}12 \\
(29.2)\end{array}$ & $\begin{array}{c}29 \\
(70.7)\end{array}$ & $\begin{array}{c}5 \\
(31.2)\end{array}$ & $\begin{array}{c}11 \\
(68.7)\end{array}$ & $3(30)$ & $7(70)$ & $0(0)$ & $3(100)$ & $\begin{array}{c}16 \\
(47.05)\end{array}$ & $18(52.9)$ \\
\hline 6. & $\begin{array}{l}\text { Cefotaxime } \\
(30)\end{array}$ & $\begin{array}{c}32 \\
(64)\end{array}$ & $18(36)$ & $\begin{array}{c}13 \\
(31.7)\end{array}$ & $\begin{array}{c}28 \\
(68.2)\end{array}$ & $4(25)$ & $12(75)$ & $4(40)$ & $6(60)$ & $0(0)$ & $3(100)$ & $\begin{array}{c}16 \\
(47.05)\end{array}$ & $18(52.9)$ \\
\hline 7. & $\begin{array}{l}\text { Ceftazidime } \\
(30)\end{array}$ & $\begin{array}{l}15 \\
(30)\end{array}$ & $35(70)$ & $9(21.9)$ & $\begin{array}{c}32 \\
(74.1)\end{array}$ & $\begin{array}{c}6 \\
(37.5)\end{array}$ & $\begin{array}{c}10 \\
(62.5) \\
\end{array}$ & $6(60)$ & $4(40)$ & $\begin{array}{c}1 \\
(33.33)\end{array}$ & $2(66.66)$ & $\begin{array}{c}14 \\
(41.17)\end{array}$ & $20(58.8)$ \\
\hline 8. & $\begin{array}{l}\text { Gentamycin } \\
\text { (10) }\end{array}$ & $\begin{array}{c}38 \\
(76)\end{array}$ & $12(24)$ & $\begin{array}{c}28 \\
(68.2)\end{array}$ & $\begin{array}{c}13 \\
(31.7)\end{array}$ & $\begin{array}{c}7 \\
(43.7)\end{array}$ & $9(56.2)$ & $6(60)$ & $4(40)$ & $\begin{array}{c}2 \\
(66.66)\end{array}$ & $1(33.33)$ & $\begin{array}{c}10 \\
(29.4)\end{array}$ & $24(70.5)$ \\
\hline
\end{tabular}


In the present study, S. aureus 126 (43.6\%) is the most common pathogen isolated. Similar studies conducted showed Neelima et al (34.3\%) (Neelima et al., 2013), Tapan at Navodaya Medical college, Raichur who also reported S.aureus (27.5\%), at Kathmandu model hospital (41.31\%) (Shrestha B, Basnet RB, 2009), another study was conducted in TUTH showed (57.7\%) (Kensekar $\mathrm{P}^{\text {et al }}$., 2003). This is comparable with that of Tiwari P, Kaur S (Tiwari P, Kaur S, 2010), Lee CY et al (Lee CY et al., 2009). However, Agnihotri N et al (Agnihotri $\mathrm{N}$ et al., 2004) found it to be second most common pathogen after Pseudomonas spp. while Klebsiella, Pseudomonas and Escherichia coli were the three leading Gram-negative isolates compared to that of Lee CY et al (Lee CY et al., 2009)

In the present study, the prevalence of MRSA is $53.96 \%$ which is higher than that reported from Nagpur (19.56\%) (Tahnkiwale SS et al., 2002) and Vellore (24\%) (Pulimood TB et al, 1996), in India. However, it is comparable to that in Mohanty et al (2004) about $38.56 \%$, United States and certain European countries where methicillin resistance was detected in $32.4 \%$ to $44.4 \%$ S.aureus isolates. (Jones ME et al., 2003)

Among the $S$. aureus, vancomycin, Ampicillin and gentamicin were the most sensitive drugs and showed least sensitivity to Cefotaxime, Erythromycin, Cotrimoxazole. Enterococcus spp showed most sensitive to ampicillin, ceftriaxone and erythromycin and least sensitive to 3rd generation cephalosporines. Gram negative isolates are most sensitive to aminoglycosides and Ceftazidime and least sensitive to Ciprofloxacin,and Cotrimoxazole. However, tests for identification of ESBL production were not performed, thus leaving further scope of evaluation.

The susceptibility pattern obtained in our study suggests that the most common organisms are gram-positive cocci, notably $S$. aureus, many of them are methicillinresistant. Therefore, empirical antibiotic treatment should be primarily directed against this pathogen. Use of single drug therapy with cephalosporins, aminoglycosides and fluoroquinolones need to be guided by the antibiogram. Hospitals should screen for MRSA among their staff and treat those who harbor them.

Periodic monitoring of susceptibility pattern need to be carried out in each hospital settings so as to detect the actual burden of antibiotic resistance in organisms and prevent the emergence of drug resistant organisms by judicial use of antibiotics. Each hospital should take proactive steps in setting up antibiotic policy guidelines and constitute a hospital infection committee to monitor the emergence of drug resistance and should implement standard work precautions among health care personnel.

Our study concludes that, majority of the pus samples yielded mono-microbial growth. S. aureus being the commonest pathogen; the role of gram negative bacilli cannot be undermined. Clinician should initiate the empirical treatment based on bacteriological and antibiogram as baseline data. The present study provides one-time information about the antibiogram which is not sufficient, as the periodic review of the bacteriological profile and antibiotic sensitivity pattern is highly essential.

\section{Acknowledgement}

The authors wish to thank the residents of the Department for providing the relevant 
data about the patients included in the study and in helping us to collect samples for culture.

\section{References}

Agnihotri N, Gupta V, Joshi RM. 2004. Aerobic bacterial isolates from burn wound infections and their antibiograms -a five year study. Burns. 30(3): 241-3.

Basu S, Ramchuran Panray T, Bali Singh T, Gulati AK, Shukla VK. 2009. A prospective, descriptive study to identify the microbiological profile of chronic wounds in outpatients. Ostomy Wound Manage. 55(1):14-20.

Betty A. Forbes, Daniel F. Sahm, Alice S. Weissfeld.2007 ; Bailey \& Scott's Diagnostic Microbiology ; 12th edition : $\mathrm{p}-210$

Collec JG, Miles RS, Wan B. Tests for the identification of bacteria. In: Collee JG, Fraser AG, Marmion BP, Simmons A, editors. Mackie \& McCartney Practical Medical Microbiology. 14th edn. Edinburg: Churchill Livingstone; 1996. pp. 13150

Jeffrey Stone A, and Paul Cianci, 1997.Diabetic wounds. Diabetes Spectrum. 4(2): 118-123.

Jones ME, Karlowsky JA, Draghi DC,Thor nsberry C, Sahm DF, Nathwani D.2003.Epidemiology and antibiotic susceptibility of bacteria causing skin and soft tissue inf ections in the USA and Europe: a guide to appropriate antimicrobial therapy. Int $\mathrm{J}$ Antimicrob Agents 22:406-19.

Kelwin W.S.1999. Anti microbial therapy for diabetic foot infections. Post Grad. Med., 106: 22-28.

Kensekar P, Pokharel BM, Tuladhar NR.2003. A study on bacteriology of wound infection and antibiotic sensitivity pattern of isolates. Fourth congress of association of clinical pathologists of Nepal(ACPN) feburary 21-22;pg 35

Koneman, W.K., Allen, S. D., Janda, W.M., Schreckenberger, P.C., Propcop, G.W., Woods, G.L. and Winn, W.C., Jr. 2005.Philadelphia Color Atlas and Textbook of Diagnostic Microbiology, 6th ed. LippincottRaven Publisher, 2005, pp: 624-662.

Krige J.E.J., and Beckingham J.I., 2001.Liver abscesses and hydatid disease. BMJ 23; 322(7285):537.

Lee CY, Chen PY, Huang FL, Lin CF. 2009.Microbiologic spectrum and susceptibility pattern of clinical isolates from the pediatric intensive care unit in a single medical center - 6 years' experience. J Microbiol Immunol Infect.42(2):160-5.

Neelima et al., 2013.Bacteriological profile of wound infection in rural hospital in R.R district Neelima ${ }^{1}$, Praveen Int. J Med Res Health Sci.2(3):469-473

Pulimood TB, Lalitha MK, Jesdason MV, Pandian R, Selwyn J, John TJ. 1996. The spectrum of antimicrobial resistance among methicillin resistant Staphylococcus aureus (MRSA) in a tertiary care centre in India. Indian $\mathbf{J}$ Med Res.103:212-5.

Ramesh Rao, S.Sumathi, K.Anuradha, D.Venkatesh, S.Krishna.2013. Bacteriology of postoperative wound infections Int $\mathrm{J}$ Pharm Biomed Res. 4(2), 72-76

Shrestha B, Basnet RB.2009. Wound infection and antibiotics sensitivity pattern of of bacterial isolation PMJN.9(1).1-5

S Mohanty, A Kapil, B Dhawan, B K das. 2004. Bacteriological and antimicrobial susceptibility profile of soft tissue infections from northern India Indian J Med Sci Vol. 58(1) 
Tayfour MA, Al-Ghamdi SM and Alahamdi AS. 2005.Surgical wound infections in King Fahed Hospital at Al-baha Saudi Med.J. 26(8):1305-07

Tahnkiwale SS, Roy S, Jalgaonkar SV.2002.Methicillins resistance among isolates of Staphylococcus aureus : antibiotic sensitivity pattern and phage typing. Ind $\mathrm{J}$ Med Sci.56:330-4.

Tiwari P, Kaur S. 2010.Profile and sensitivity pattern of bacteria isolated from various cultures in a Tertiary Care Hospital in Delhi. Indian $\mathbf{J}$ Public Health.54(4):213-5.

Clinical and Laboratory Standard Institute; Performance standards for antimicrobial susceptibility testing; Clinical and Laboratory Standards Institute, Wayne; 2012; 22nd Informational Supplement: 32(3).

\section{How to cite this article:}

Pushpalatha Hanumanthappa, B. Vishalakshi and Krishna S. 2016. A Study on aerobic Bacteriological profile and Drug sensitivity pattern of Pus samples in a tertiary care hospital.

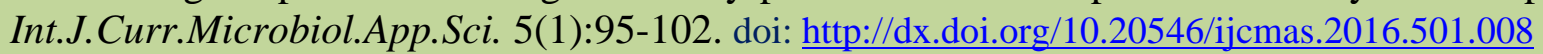

